\title{
Are $F e$ and $P$ availabilities involved in determining the occurrence and distribution of Calluna vulgaris (L.) Hull in semi-arid grasslands on calcareous soils?
}

\author{
Christoph Fühner • Michael Runge
}

Received: 10 June 2008 / Accepted: 28 August 2008 / Published online: 30 September 2008

(C) The Author(s) 2008. This article is published with open access at Springerlink.com

\begin{abstract}
Calluna vulgaris (L.) Hull is primarily found on acid soils and is generally classified as a calcifuge species. Therefore, its occasional growth in semi-arid grassland on shallow calcareous soils gave rise to the question as to whether special soil conditions, deviating from the typical conditions in calcareous soils, enable this unusual occurrence. In an attempt to answer this question, we analysed selected soil factors, comparing plots where $C$. vulgaris was growing besides calcicole species ( $=\mathrm{CF}$ plots) with neighbouring plots where only calcicole species were present ( $=\mathrm{CC}$ plots). Main emphasis was placed on $\mathrm{Fe}$ and $\mathrm{P}$ availability because results from growth experiments indicate that the availability of either Fe or P to calcifuges causes calcifuge species to fail on calcareous soils. The results of our investigations do not support the hypothesis that the occurrence of $C$. vulgaris in semi-arid calcareous grasslands depends on higher $\mathrm{Fe}$ and/or P availability.
\end{abstract}

Responsible Editor: Philippe Hinsinger.

C. Fühner $\cdot$ M. Runge

Albrecht-von-Haller-Institute for Plant Sciences,

Department of Ecology and Ecosystems Research, University of Göttingen,

Untere Karspüle 2,

37073 Göttingen, Germany

C. Fühner $(\bowtie)$

Helmholtz Centre for Environmental Research - UFZ,

Department for Computational Landscape Ecology,

Permoserstr. 15,

D-04318 Leipzig, Germany

e-mail: cfuehne@gwdg.de
Rather, its growth on carbonate-buffered soils shows that this species is not really calcifuge. Since the CF plots differ from the $\mathrm{CC}$ plots either by a lower inclination or by a more northerly exposition, we assume that the primary establishment and this species' distribution pattern in the investigated semi-arid grassland are not dependent on soil chemical factors, but are governed by topography and its consequences for soil humidity and drought stress.

Keywords Calluna vulgaris · Calcifuge plants . Semi-arid grassland $\cdot$ Calcareous soils . Iron availability $\cdot$ Phosphate availability

\section{Introduction}

C. vulgaris (L.) Hull is normally regarded as a calcifuge species (Gimingham 1960; Ellenberg et al. 1992) because it is a frequent component of various vegetation types on acid to very acid soils. However, the species occurs occasionally even in semi-arid grasslands on shallow calcareous soils, where it grows in mixtures with calcicole plant species (Grubb et al. 1969). Under conditions where calcareous soils are superficially acidified or where layers of non-calcareous, acidic material, as e.g. loess or humus, overlie the calcareous soil material, the occurrence of $C$. vulgaris is still in accordance with its calcifuge classification. However, there are also sites where this and other species, regarded as more or less calcifuge, are present on 
calcareous soils that lack such acidic layers and where the root system of these plants penetrate almost down to the bedrock. Such cases raise the question as to whether special soil conditions, deviating from normal conditions in calcareous soils, allow the growth of these species or whether they are not calcifuge in a strict sense.

Examples of sites where C. vulgaris and some moderately calcifuge species grow in mixtures with calcicole species are to be found in semi-arid calcareous grasslands in southern Lower Saxony and northern Hesse in the centre of Germany. In these cases the calcifuge species are not equally distributed over the total area but occur in scattered patches. This offers a possibility to answer the question, raised above, by comparing soils at plots where $C$. vulgaris is mixed with calcicole and indifferent species with soils at plots where exclusively calcicole and indifferent species are growing. If soil factors that differ between these locations could be identified, this would contribute to an answer to the more general question of why calcifuge species normally avoid calcareous soils.

Above all, two factors deserve particular attention in this context:

(a) Soil iron solubility is, as a general rule, minimal between $\mathrm{pH} 7.4$ and $\mathrm{pH} 8.5$, i. e., within the $\mathrm{pH}$ range of $\mathrm{CaCO}_{3}$ buffering at typical partial pressures of $\mathrm{CO}_{2}$ in the soil solution (Lindsay 1979). In addition, uptake and metabolism of $\mathrm{Fe}$ are disturbed by high pH (Susin et al. 1996; Kosegarten et al. 1999) and high $\mathrm{HCO}_{3}{ }^{-}$concentrations (Lee and Woolhouse 1969a, b; Mengel 1994). As both factors are usually high in calcareous soils, plants lacking the ability to solubilize, to take up, or to metabolise Fe under these conditions can be expected to fail. For a long time, this has been assumed to be decisive for the exclusion of calcifuge species from calcareous soils (Grime 1963). In fact, a weaker ability to acquire and to utilise $\mathrm{Fe}$ has been observed in several calcifuge plants in comparison to calcicole ones (Snaydon and Bradshaw 1962; Grime and Hodgson 1969; Gries and Runge 1995; Zohlen and Tyler 2000).

(b) Plant phosphate availability is restricted in calcareous soils because high $\mathrm{Ca}^{2+}$ concentrations and high $\mathrm{pH}$ lead to precipitation of $\mathrm{Ca}$ phosphates and, ultimately, to the formation of apatites
(Lindsay et al. 1989). P deficiency has been found to prevent several calcifuge species from growing on calcareous soils (Tyler 1992, 1994; Zohlen and Tyler 2004), and has been explained by assuming a weaker ability of these species to solubilize phosphate compared to calcicole species (Ström et al. 1994; Tyler and Ström 1995; Ström 1997).

Proceeding from these considerations, we hypothesised that (a) Fe availability or (b) P availability is favoured by special soil conditions in patches where C. vulgaris grows together with calcicole species compared to patches where only calcicole species are found. To test this hypothesis, we determined the soil contents of different fractions of $\mathrm{Fe}$ and $\mathrm{P}$ together with other factors that influence the availability of these elements, applying both standard and novel extraction methods.

\section{Material and methods}

Study sites

Detailed investigations were performed for two semiarid calcareous grasslands (study sites I and II) situated on a Triassic limestone plateau north of Kassel, Germany. In addition to these main sites investigations were conducted for comparable semi-arid calcareous grasslands at four supplementary sites. The study sites III and IV are adjacent to the main sites, whereas the sites V and VI are located at the south-western foothills of the Harz mountains (Table 1).

Parent material of soil formation at study sites I-IV is limestone originating from Lower Muschelkalk, at sites V-VI carbonate-rich sediments of the Stassfurt series in the Upper Permian Zechstein formation. According to the WRB classification, soil types are either shallow rendzic leptosol or mollic leptosols with a somewhat deeper solum (FAO 2006; Table 3). These soils are representative for calcareous grasslands in Central Western Europe (Niklaus and Falloon 2006). Soil organic carbon contents $\left(C_{\mathrm{o}}\right)$ mostly range between $2.0 \%$ and $6.0 \%\left(\mathrm{~m} / \mathrm{m}_{\mathrm{DW}}\right)$, corresponding to carbon contents widespread in calcareous soils under temperate climatic conditions (e.g. Misra and Tyler 1999; Niklaus 1998; Dušek 1995).

Plots of $100 \mathrm{~m}^{2}(10 \times 10 \mathrm{~m})$ were installed both in patches with and without $C$. vulgaris at the main sites 
Table 1 Study sites

\begin{tabular}{|c|c|c|c|c|}
\hline No. & Study site & Study area & $\begin{array}{l}\text { District/ } \\
\text { Fed. state }\end{array}$ & Coordinates \\
\hline I & Auf der Burg & $\begin{array}{l}\text { Unteres } \\
\text { Diemeltal }\end{array}$ & $\begin{array}{c}\text { Kassel/ } \\
\text { Hesse }\end{array}$ & $\begin{array}{r}9.393 \mathrm{O} \\
51.594 \mathrm{~N}\end{array}$ \\
\hline II & Hölleberg & $\begin{array}{l}\text { Unteres } \\
\text { Diemeltal }\end{array}$ & $\begin{array}{c}\text { Kassel/ } \\
\text { Hesse }\end{array}$ & $\begin{array}{r}9.406 \mathrm{O} \\
51.613 \mathrm{~N}\end{array}$ \\
\hline III & Stahlberg & $\begin{array}{l}\text { Unteres } \\
\text { Diemeltal }\end{array}$ & $\begin{array}{r}\text { Kassel/ } \\
\text { Hesse }\end{array}$ & $\begin{array}{r}9.389 \mathrm{O} \\
51.607 \mathrm{~N}\end{array}$ \\
\hline IV & Flohrberg & $\begin{array}{l}\text { Unteres } \\
\text { Diemeltal }\end{array}$ & $\begin{array}{c}\text { Kassel/ } \\
\text { Hesse }\end{array}$ & $\begin{array}{r}9.383 \mathrm{O} \\
51.587 \mathrm{~N}\end{array}$ \\
\hline $\mathrm{V}$ & Pagenberg & $\begin{array}{l}\text { Foreland of } \\
\text { Harz mountains }\end{array}$ & $\begin{array}{l}\text { Osterode/ } \\
\text { Lower } \\
\text { Saxony }\end{array}$ & $\begin{array}{l}10.197 \mathrm{O} \\
51.758 \mathrm{~N}\end{array}$ \\
\hline VI & Steinkirche & $\begin{array}{l}\text { Foreland of } \\
\text { Harz mountains }\end{array}$ & $\begin{array}{l}\text { Osterode/ } \\
\text { Lower } \\
\text { Saxony }\end{array}$ & $\begin{array}{l}10.380 \mathrm{O} \\
51.634 \mathrm{~N}\end{array}$ \\
\hline
\end{tabular}

Geographical coordinates are given decimally. Main sites in bold

I and II (in the following, plots with C. vulgaris are denoted CF plots, the others CC plots, the soils analogously as $\mathrm{CF}$ soils and $\mathrm{CC}$ soils). The plots areas were divided into 16 subplots $(2.5 \times 2.5 \mathrm{~m})$. The vegetation was recorded in eight alternating subplots. At the supplementary sites III-VI plants were recorded in a $2.5 \times 2.5 \mathrm{~m}$ plot within each vegetation type. The nomenclature follows Wisskirchen and Häupler (1998) for phanerogams and Koperski et al. (2000) for bryophytes. The complete lists of the species and the results of detailed plant sociological surveys of the study sites are given in Fühner (2005).

Soil sampling and preparation of soil material

Soil depths were determined by inserting a graduated metal rod in regular intervals (145 insertions per plot at the main sites, 10 insertions per plot at the supplementary sites). Soil samples were taken from the upper $10 \mathrm{~cm}$ of the $\mathrm{A}_{\mathrm{h}}$-horizon using a brass cylinder (height $118 \mathrm{~mm}$, inner diameter $52 \mathrm{~mm}$ ). Above-ground plant material and the organic layer were removed, the upper $200 \mathrm{ml}$ of the soil columns filled into PE bags, transported to the laboratory in a cool box and stored at $4^{\circ} \mathrm{C}$ until preparation for soil analyses.

Soil material was sampled at the main sites, I and II, on seven dates distributed across the year. On each date samples were taken from eight alternating subplots within each vegetation type. At the supple- mentary sites III-VI, soil sampling was done only once. Four samples were taken there at random within the plots where the vegetation analyses had been made.

Soil material was weighed and sieved $(2 \mathrm{~mm}$ mesh) within $24 \mathrm{~h}$ after sampling. The coarse material was washed, divided into skeleton material and roots, dried and weighed. Fine soil homogenates were used for further procedures either field-moist or air-dried.

Determination of water content and weight density of fine soil

The water content of the field-moist fine soil homogenate was determined by drying subsamples of $10 \mathrm{~g}$ at $106^{\circ} \mathrm{C}$ and cooling them in a desiccator before weighing. Based on the gravimetric water content of the fine soil homogenate and the specific density of the skeleton material $(2.65 \mathrm{~g} / \mathrm{ml})$ the volumetric water content $\Theta$ and the weight density $\rho$ of the fine soil fraction of the intact soil columns were calculated.

Preparation of equilibrium soil solutions (ESS)

ESS were prepared in accordance with Ludwig et al. (1999). After sieving, $\mathrm{H}_{2} \mathrm{O}$ demin. was added to $25 \mathrm{~g}$ field-moist fine soil in a $100 \mathrm{ml}$ Erlenmeyer flask to such an amount that under consideration of the actual water content a soil/water ratio of 1:2 was attained. The flask was sealed and shaken horizontally for $24 \mathrm{~h}$. Subsequently, the soil suspension was centrifuged twice ( $2 \mathrm{~min}, g_{\max }=100,000 \times g, T=4^{\circ} \mathrm{C}$ ), the supernatant filtered through cellulose acetate filter (Sartorius, $0.45 \mu \mathrm{m}$ ), and the filtrate stored at $4^{\circ} \mathrm{C}$ until analysis.

Determination of effective cation exchange capacities $\left(\mathrm{CEC}_{\mathrm{eff}}\right)$

$\mathrm{CEC}_{\text {eff }}$ was determined following Falkengren-Grerup et al. (1995). A suspension of $5.0 \mathrm{~g}$ air-dry fine soil in $50 \mathrm{ml} 0.1 \mathrm{M} \mathrm{BaCl}_{2}$ was shaken for $2 \mathrm{~h}$ in a $100 \mathrm{ml}$ Erlenmeyer flask. Subsequently, the suspension was centrifuged $(10 \mathrm{~min}, 1,500 \times g)$ and the supernatant filtered (Schleicher \& Schuell $589^{3}$ ). The $\mathrm{pH}$ of the filtrate was measured electrometrically, the cation 
concentrations were determined by atomic absorption spectrophotometry (AAS).

Non-sequential fractionation of iron

To evaluate the plant Fe availability at the study sites, field moist fine soil was extracted with $\mathrm{H}_{2} \mathrm{O}$ demin. and with solutions of Ferrozine, DTPA, NTA, and Oxalate.

Ferrozine (PDTS, 3-(2-Pyridyl)-5,6-diphenyl1,2,4-triazin-4',4" disulfonic acid monosodium salt) forms a stable $3: 1$ complex with $\mathrm{Fe}^{2+}$ that can be used for colorimetric quantification of ferrous iron. In order to minimise oxidative Fe precipitation during the extraction $20 \mathrm{~g}$ field-moist fine soil were mixed immediately after sieving the bulk soil with $60 \mathrm{ml}$ of $500 \mu M$ Ferrozine solution. After shaking the suspension horizontally for $24 \mathrm{~h}$ and ultracentrifugation (30 min, $g_{\max }=100000 \cdot \mathrm{g}, \mathrm{T}=4^{\circ} \mathrm{C}$ ) ferrous iron in the supernatant was determined photometrically.

DTPA (diethylenetriaminepentaacetic acid) is widely used for the quantification of "plant-available" $\mathrm{Fe}$, but also of $\mathrm{Cu}, \mathrm{Mn}$ and $\mathrm{Zn}$ in calcareous soils. Solutions of DTPA $(5 \mathrm{~m} M)$, buffered with triethanolamine $(0.1 M)$ to $\mathrm{pH} 7.3$, extract mainly an exchangeable fraction of the metals (Lindsay and Norvell 1978). In order to prevent the dissolution of $\mathrm{CaCO}_{3}$ from the soil material $0.01 \mathrm{M} \mathrm{CaCl}_{2}$ were added to the extractant. Suspensions of $25 \mathrm{~g}$ fieldmoist fine soil and $50 \mathrm{ml}$ extractant solution were shaken for $4 \mathrm{~h}$ (deviating from the original protocol) before being filtered through filter paper (Schleicher \& Schuell $589^{3}$ ).

NTA (nitrilotriacetate) was used to determine organically bound Fe. Following Yuan et al. (1993), $50 \mathrm{ml}$ of $0.1 M$ NTA solution (pH 8.3) were added to $1.0 \mathrm{~g}$ field-moist fine soil, and the suspension was shaken for $24 \mathrm{~h}$ before filtering through filter paper (Schleicher \& Schuell $589^{3}$ ). A preceding treatment of the soil homogenate with $0.01 \mathrm{M} \mathrm{HCl}$, included in the original protocol, was omitted because it reduced the extracted $\mathrm{Fe}$ amount from air-dry fine soil homogenates in preliminary experiments for $2.6 \%$ only.

Oxalate was used to quantify amorphous, noncrystalline Fe-(oxy/hydr)oxides. Being a strong ligand, oxalate also extracts $\mathrm{Fe}$ from organic compounds (Campbell and Schwertmann 1984; Borggaard 1988). For the extraction $50 \mathrm{ml}$ ammoni- um oxalate/oxalic acid (0.2 M, pH 3.25) were added to $5.0 \mathrm{~g}$ field-moist fine soil. The suspension was shaken for $4 \mathrm{~h}$ in darkness and finally filtered (Schleicher \& Schuell 589 $9^{3}$.

Sequential $\mathrm{P}$ fractionation

The plant $\mathrm{P}$ availability at the study sites was evaluated according to the sequential fractionation scheme of Tiessen and Moir (1993) with $\mathrm{H}_{2} \mathrm{O}$ in the presence of an anion exchange resin, $\mathrm{NaHCO}_{3}, \mathrm{NaOH}$, and $\mathrm{HCl}$. Residual $\mathrm{P}$ fractions were not extracted because their importance in the P supply to plants is insignificant. In each step $30 \mathrm{ml}$ of the extractant were added to $0.5 \mathrm{~g}$ air-dried, ground soil material in polycarbonate tubes, and the suspensions were shaken vertically for $16 \mathrm{~h}$. Solution and solid matter were separated by ultracentrifugation ( $30 \mathrm{~min}, g_{\max }=25,000 \times g, T=4^{\circ} \mathrm{C}$ ). Remaining particles were removed by filtering the supernatant through a cellulose acetate filter $(0.45 \mu \mathrm{m}$, Sartorius $)$ before photometric $\mathrm{P}$ analyses.

To determine the water soluble and easily exchangeable $\mathrm{P}_{\text {resin }}$ a basic anion exchanger (Dowex ${ }^{\circledR} 1 \times 8,20$ 50 mesh) was used. A polyethylene net containing $4 \mathrm{~cm}^{3}$ of the exchanger was added to $500 \mathrm{mg}$ of the soil material and $30 \mathrm{ml} \mathrm{H}_{2} \mathrm{O}$ demin. After shaking, the attached soil material was rinsed off the net twice with $10 \mathrm{ml} \mathrm{H}_{2} \mathrm{O}$ demin. $\mathrm{P}$ was desorbed by shaking the net for $30 \mathrm{~min}$ in $25 \mathrm{ml} 0.5 \mathrm{M} \mathrm{HCl}$. Before the next step, extraction and rinsing solutions were combined, and the solid matter was separated from the combined solutions by centrifugation.

$\mathrm{NaHCO}_{3}$ was used to determine exchangeable $\mathrm{P}$ as well as inorganic and organic $\mathrm{P}$ that is weakly bound to soil aggregates (Olsen-P). Because of the high respiration rates in the rhizosphere, which promote the dissolution of $\mathrm{CaCO}_{3}$ as well as the desorption of $\mathrm{P}$ by $\mathrm{HCO}_{3}{ }^{-}$, this method characterises a plant available $\mathrm{P}$ fraction especially in calcareous soils. As the proportions of the dissociation species in the carbonate system are $\mathrm{pH}$-dependent and to ensure a concentration of $0.5 \mathrm{M} \mathrm{HCO}_{3}^{-}$, the $\mathrm{NaHCO}_{3}$ solution was brought to $\mathrm{pH} 8.5$ with $\mathrm{NaOH}$.

Hydroxide ions dissolve $\mathrm{P}$ that is fixed to $\mathrm{Fe}$ and Al (hydr)oxides as well as $\mathrm{P}$ from base-soluble organic substances. For the extraction of this fraction $0.1 \mathrm{M} \mathrm{NaOH}$ was used.

To extract the $\mathrm{P}$ fraction that is bound as apatite, the soil material was finally shaken with $1.0 \mathrm{M} \mathrm{HCl}$. 
Analytical procedures

Actual acidities $\left(\mathrm{pH}_{\mathrm{H} 2 \mathrm{O}}\right)$ and potential acidities $\left(\mathrm{pH}_{\mathrm{KCl}}\right)$ were determined electrometrically in $10 \mathrm{~g}$ of field-moist fine soil equilibrated with $20 \mathrm{ml}$ of $\mathrm{H}_{2} \mathrm{O}$ demin. and $1.0 \mathrm{M} \mathrm{KCl}$ solutions, respectively. Additionally, $\mathrm{pH}$ was measured in the ESS and in the solutions of the CEC determination.

The carbonate content of the fine soil was measured volumetrically with a Scheibler apparatus, based on the release of $\mathrm{CO}_{2}$ when $\mathrm{HCl}$ is added to the soil (Loeppert and Suarez 1996).

Total contents of $\mathrm{C}$ and $\mathrm{N}$ were measured with a $\mathrm{C}-\mathrm{N}$ analyser (Carlo Erba NA 1500) in $10 \mathrm{mg}$ airdried and ground fine soil. The contents of organic $\mathrm{C}$ were calculated by subtracting the inorganic $\mathrm{C}$ content from total $\mathrm{C}$.

DOC concentrations in the ESS of CF soils and CC soils from the main sites were analysed for one sampling date using a TOC analyser (Shimadzu TOC5000/5050).

The $\mathrm{P}$ and $\mathrm{NO}_{3}{ }^{-}$concentrations of the ESS were measured by ion chromatography, using a combined Gynkotek/Waters HPLC system controlled by the Dionex chromatography software Chromeleon (version 4.20). Because of the high cation contents of the ESS a preparative cation exchange had to be performed before anion analysis. About $1 \mathrm{ml}$ ESS was poured into a tube filled with a cation exchanger (Amberlite CG-120II, 200-400 mesh). The first few drops were discarded, and the rest was filled directly into an autosampler vial. For details of the HPLC analyses refer to Fühner (2005).

The Fe concentrations in the ESS and in the extracts of the non-sequential $\mathrm{Fe}$ fractionation as well as the concentrations of $\mathrm{Na}, \mathrm{K}, \mathrm{Mg}, \mathrm{Ca}, \mathrm{Mn}, \mathrm{Fe}, \mathrm{Al}$, and $\mathrm{Zn}$ in the extracts for the $\mathrm{CEC}_{\mathrm{eff}}$ determination were measured by AAS (Varian SpectrAA 30).

The ferrous iron concentrations in the Ferrozine extracts were measured by photometry at $\lambda=$ $562 \mathrm{~nm}$ based on an extinction coefficient of $\varepsilon=$ $24.6 \mathrm{mM}^{-1} \mathrm{~cm}^{-1}$.

Following Murphy and Riley (1962), the formation of a molybdate complex was used to determine $\mathrm{P}$ by photometry at $\lambda=712 \mathrm{~nm}$. In preliminary tests the quantity of $\mathrm{NaOH}$ or $\mathrm{H}_{2} \mathrm{SO}_{4}$ that was necessary to bring the different soil extracts to $\mathrm{pH} 5.4$, the optimal $\mathrm{pH}$ for the formation of the blue-coloured complex, was established. Calibrations of the photometric tests were performed separately for each extract type at concentrations between 0 and $20 \mu \mathrm{M}$ P. The extinction coefficients varied between $15.8 \mathrm{mM}^{-1} \mathrm{~cm}^{-1}$ (resin extractable P) and $17.3 \mathrm{mM}^{-1} \mathrm{~cm}^{-1}\left(\mathrm{HCO}_{3}{ }^{-}\right.$extractable P).

Data analyses

For most investigations, data analyses were performed using the SPSS for Windows 8.0 Statistical Package. Normal distribution and homogeneity of variance were tested using the Shapiro-Wilk test and the Levene test, respectively. If the premises were met for all data sets in an investigation series, mean comparisons of two samples were conducted by $t$ tests, multiple comparisons by one-way ANOVA followed by post hoc Scheffé tests. In all other cases, non-parametric statistics were applied. Two samples were compared here by Mann-Whitney $U$ tests, more than two samples by applying Kruskal-Wallis $H$ tests followed by post hoc pairwise Schaich-Hamerle comparisons performed by a Microsoft EXCEL AddIn programmed in Visual Basic.

SigmaPlot for Windows (version 6.0, Systat Software Inc.) was used for linear and non-linear regression analyses. Data sets were tested here for normality by the Kolmogorov-Smirnov procedure, for constant variance by computing the Spearman rank correlations between the absolute values of the residuals and the observed values of the dependent variables. Durbin-Watson tests were used to check the assumption that the residuals are independent of each other, rejecting the null hypothesis if the Durbin-Watson values deviated from 2 by more than 0.50. In addition to the regression equations, the adjusted coefficients of determination $r_{\text {adj }}^{2}$ and the results for one-way ANOVA were recorded.

\section{Results}

Plant species composition

C. vulgaris, given the reaction value 1 (strictly calcifuge) by Ellenberg et al. (1992), is present in all $\mathrm{CF}$ plots at the main sites and in the CF plots of three of the supplementary sites, covering between $<5 \%$ and $>25 \%$ of the individual plots. At site $\mathrm{V}$, it is missing, but according to an information from the 
nature conservation authority it was recorded there until at least 1993. Therefore, and because of the frequent occurrence of Danthonia decumbens L. (reaction value 3 , moderately calcifuge) in the $\mathrm{CF}$ plot the site was included into the investigations. $D$. decumbens also occurs frequently in CF plots at the other sites. The calcifuge moss Pleurozium schreberi (Brid.) Mitt. is present in all CF plots at the main sites but is absent at the supplementary sites. Except for these species, only two other moderately calcifuge species [Luzula campestris (L.) Dc., Polygala vulgaris L.] were found in a few cases (Table 2). On the other hand, calcicole species are numerous at all sites even on the CF plots.
General soil conditions and $\mathrm{pH}$ values

$\mathrm{CC}$ and $\mathrm{CF}$ plots of the main sites differ in several respects (Table 3): CC plots, except for site $\mathrm{V}$, are situated on steeper slopes than CF plots, and the latter tend to have a more northerly orientation. CF soils are deeper (except for site $\mathrm{V}$ ), and their $\mathrm{CaCO}_{3}$ content is lower. According to the US Soil Taxonomy the soil texture of all plots is silt loam.

Tendentially, the soil $\mathrm{pH}$ is lower on the CF plots than at the $\mathrm{CC}$ plots, in accordance with the lower $\mathrm{CaCO}_{3}$ contents and lower base saturations. However, the $\mathrm{pH}_{\mathrm{H} 2 \mathrm{O}}$ was generally high even in $\mathrm{CF}$ soils. A $\mathrm{pH}_{\mathrm{H} 2 \mathrm{O}}<6.0$ was found only in one case, and in four

Table 2 Occurrence of calcicole and calcifuge plant species on CC plots and CF plots at the study sites I $(n=8)$, II $(n=8)$ and III $=$ VI $(\mathrm{n}=4)$

\begin{tabular}{|c|c|c|c|c|c|c|c|}
\hline & \multirow[t]{2}{*}{$R$} & \multicolumn{2}{|c|}{ Site I } & \multicolumn{2}{|c|}{ Site II } & \multicolumn{2}{|c|}{ Sites IV-VI } \\
\hline & & $\mathrm{CC}$ & $\mathrm{CF}$ & $\mathrm{CC}$ & $\mathrm{CF}$ & $\mathrm{CC}$ & $\mathrm{CF}$ \\
\hline \multicolumn{8}{|l|}{ Calcicole species in CC plots and CF plots } \\
\hline Carex flacca Schreb. & 8 & 8 & 8 & 8 & 8 & 4 & 4 \\
\hline Scabiosa columbaria $\mathrm{L}$. & 8 & 8 & 8 & 8 & 8 & 4 & 4 \\
\hline Cirsium acaule Scop. & 8 & 8 & 8 & 8 & 8 & 3 & 4 \\
\hline Pimpinella saxifraga $\mathrm{L}$. & 8 & 7 & 7 & 8 & 8 & 3 & 3 \\
\hline Sanguisorba minor Scop. & 8 & 8 & 3 & 8 & 7 & 3 & 3 \\
\hline Plantago media $\mathrm{L}$. & 7 & 8 & 8 & 8 & 8 & 4 & 4 \\
\hline Lotus corniculatus L. & 7 & 8 & 8 & 8 & 8 & 4 & 4 \\
\hline Brachypodium pinnatum (L.) $\mathrm{Pb}$. & 7 & 8 & 8 & 8 & 8 & 3 & 3 \\
\hline Potentilla neumanniana Rchb. & 7 & 8 & 8 & 8 & 7 & 2 & 1 \\
\hline Ranunculus bulbosus L. & 7 & 8 & 8 & 6 & 7 & 3 & 1 \\
\hline Linum catharticum L. & 7 & 8 & 7 & 8 & 8 & 3 & 4 \\
\hline Koeleria pyramidata (Lam.) P.B. & 7 & 8 & 6 & 8 & 8 & 4 & 4 \\
\hline Leontodon hispidus L. & 7 & 8 & 6 & 8 & 8 & 3 & 4 \\
\hline Carlina vulgaris $\mathrm{L}$. & 7 & 8 & 7 & 8 & 3 & 3 & 1 \\
\hline Anthyllis vulneraria $\mathrm{L}$. & 7 & 8 & 5 & 5 & 0 & 1 & 1 \\
\hline \multicolumn{8}{|l|}{ Calcicole species, mainly in CC plots } \\
\hline Ditrichum flexicaule (Schwaegr.) Hampe & 9 & 8 & 0 & 3 & 0 & 1 & 0 \\
\hline Ctenidium molluscum (Hedw.) Schimp. & 8 & 8 & 0 & 6 & 0 & 2 & 1 \\
\hline Medicago lupulina L. & 8 & 4 & 2 & 7 & 5 & 1 & 0 \\
\hline Galium verum $\mathrm{L}$. & 7 & 7 & 1 & 2 & 1 & 0 & 1 \\
\hline Fissidens taxifolius Hedw. & 7 & 1 & 0 & 4 & 0 & 0 & 0 \\
\hline Campanula rapunculoides $\mathrm{L}$. & 7 & 3 & 0 & 2 & 0 & 0 & 1 \\
\hline \multicolumn{8}{|l|}{ Calcifuge species, mainly in CF plots } \\
\hline Agrostis tenuis Sibth. & 4 & 0 & 8 & 0 & 5 & 1 & 2 \\
\hline Danthonia decumbens L. & 3 & 0 & 8 & 0 & 5 & 1 & 3 \\
\hline Luzula campestris (L.) Dc. & 3 & 0 & 0 & 0 & 1 & 0 & 1 \\
\hline Polygala vulgaris L. & 3 & 0 & 0 & 0 & 1 & 0 & 1 \\
\hline Pleurozium schreberi (Brid.) Mitt. & 2 & 0 & 8 & 1 & 8 & 0 & 0 \\
\hline Calluna vulgaris (L.) Hull & 1 & 0 & 8 & 1 & 8 & 0 & 3 \\
\hline
\end{tabular}

$\mathrm{R}$ refers to indicator values for soil acidity according to Ellenberg et al. (1992): 1 = plants growing always on extremely acid soils, $9=$ plants growing always on calcareous soils 
Table 3 Topographical, floristic and median pedological characteristics of CC plots and CF plots

\begin{tabular}{|c|c|c|c|c|c|c|c|c|c|c|c|c|}
\hline & \multicolumn{2}{|c|}{ Site I } & \multicolumn{2}{|c|}{ Site II } & \multicolumn{2}{|c|}{ Site III } & \multicolumn{2}{|c|}{ Site IV } & \multicolumn{2}{|c|}{ Site V } & \multicolumn{2}{|c|}{ Site VI } \\
\hline & $\mathrm{CC}$ & $\mathrm{CF}$ & $\mathrm{CC}$ & $\mathrm{CF}$ & $\mathrm{CC}$ & $\mathrm{CF}$ & $\mathrm{CC}$ & $\mathrm{CF}$ & $\mathrm{CC}$ & $\mathrm{CF}$ & $\mathrm{CC}$ & $\mathrm{CF}$ \\
\hline HASL (m) & 240 & 225 & 245 & 245 & 230 & 230 & 210 & 210 & 225 & 250 & 290 & 310 \\
\hline Exposure & $\mathrm{NE}$ & ENE & $\mathrm{E}$ & NNE & SW & SW & $\mathrm{NE}$ & NNE & SW & W & SW & WSW \\
\hline Inclination & $16^{\circ}$ & $5^{\circ}$ & $18^{\circ}$ & $10^{\circ}$ & $14^{\circ}$ & $10^{\circ}$ & $10^{\circ}$ & $10^{\circ}$ & $13^{\circ}$ & $4^{\circ}$ & $29^{\circ}$ & $10^{\circ}$ \\
\hline Species number & 35 & 36 & 38 & 41 & 34 & 36 & 46 & 36 & 39 & 44 & 30 & 55 \\
\hline Soil depth $(\mathrm{cm})$ & 9.0 & $15.5 * * *$ & 10.0 & $12.5^{* * *}$ & 8.0 & $21.0^{*}$ & 9.0 & $23.5^{*}$ & 15.0 & $11.0^{*}$ & 40.0 & $>40^{*}$ \\
\hline $\mathrm{pH}_{\mathrm{H} 2 \mathrm{O}}$ & 8.0 & $7.4 * * *$ & 7.9 & $7.9^{\text {n.s. }}$ & 7.8 & $7.4^{*}$ & 7.7 & $5.8 *$ & 7.8 & $6.0^{*}$ & 7.8 & $7.7^{\text {n.s. }}$ \\
\hline $\mathrm{pH}_{\mathrm{KCl}}$ & 7.1 & $4.8 * * *$ & 7.0 & $6.2 * * *$ & 7.0 & $6.5^{*}$ & 6.9 & $4.3^{*}$ & 6.9 & $4.5^{*}$ & 7.4 & $6.6^{*}$ \\
\hline $\mathrm{CaCO}_{3}\left(\% \mathrm{~m} / \mathrm{m}_{\mathrm{FS}-\mathrm{DW}}\right)$ & 31.2 & $0.5 * * *$ & 14.6 & $1.4 * * *$ & 4.0 & $0.1^{*}$ & 1.8 & $0.3 *$ & 3.7 & $0.3 *$ & 80.8 & $10.8^{*}$ \\
\hline $\mathrm{C}_{\mathrm{o}}\left(\% \mathrm{~m} / \mathrm{m}_{\mathrm{FS}-\mathrm{DW}}\right)$ & 5.9 & $5.3 * * *$ & 6.6 & $5.7 * * *$ & 4.2 & $4.5^{\text {n.s. }}$ & 4.2 & $2.9^{\text {n.s. }}$ & 4.0 & $4.4^{\text {n.s. }}$ & $0.0^{\mathrm{a}}$ & $2.1^{\text {n.s. }}$ \\
\hline $\mathrm{N}\left(\% \mathrm{~m} / \mathrm{m}_{\mathrm{FS}-\mathrm{DW}}\right)$ & 0.52 & $0.43 * * *$ & 0.59 & $0.48 * * *$ & 0.36 & $0.36^{\text {n.s. }}$ & 0.35 & $0.22^{\text {n.s. }}$ & 0.31 & $0.35^{\text {n.s. }}$ & 0.34 & $0.23^{\text {n.s. }}$ \\
\hline $\mathrm{C}_{\mathrm{o}} / \mathrm{N}\left(\mathrm{m} / \mathrm{m}_{\mathrm{FS}-\mathrm{DW}}\right)^{\mathrm{b}}$ & 11.4 & $12.1 * * *$ & 11.0 & $11.9 * * *$ & 11.7 & $13.0^{\text {n.s. }}$ & 11.6 & $13.3^{\text {n.s. }}$ & 12.8 & $12.7^{\text {n.s. }}$ & 12.3 & $13.4 *$ \\
\hline $\mathrm{NO}_{3}{ }^{-}$ESS $\left(\mathrm{nmol} / \mathrm{g}_{\mathrm{FS}-\mathrm{DW}}\right)$ & 31.5 & $1.4 * * *$ & 7.7 & $3.4^{*}$ & 7.4 & $0.9^{\text {n.s. }}$ & 264 & $4.3^{*}$ & 20.6 & $0.2^{*}$ & 427 & $44.0^{*}$ \\
\hline Skeleton material $\left(\% \mathrm{~V} / \mathrm{V}_{\mathrm{t}}\right)$ & 28.4 & $0.7 * * *$ & 19.4 & $7.9 * * *$ & & & & & & & & \\
\hline Fine soil density $\rho\left(\mathrm{kg}_{\mathrm{DW}} / \mathrm{l}\right)$ & 0.73 & $1.02 * * *$ & 0.81 & $0.94 * * *$ & & & & & & & & \\
\hline Water content $\Theta\left(\% \mathrm{~V} / \mathrm{V}_{\mathrm{FS}}\right)$ & 25.7 & $44.0 * * *$ & 34.0 & $41.7 * * *$ & & & & & & & & \\
\hline DOC $\left(\mu \mathrm{g} / g_{\text {FS-DW }}\right)$ & 24.3 & $30.8^{*}$ & 23.8 & $30.3 * *$ & & & & & & & & \\
\hline $\mathrm{CEC}_{\text {eff }}\left(\mathrm{mmol}_{\mathrm{c}} / 100 \mathrm{~g}_{\mathrm{FS}-\mathrm{DW}}\right)$ & 16.7 & $14.3 * * *$ & 18.3 & $16.6^{* * *}$ & & & & & & & & \\
\hline $\mathrm{BS}\left(\% \mathrm{CEC}_{\mathrm{eff}}\right)$ & 100 & $99.0 * * *$ & 100 & $99.5^{* * *}$ & & & & & & & & \\
\hline
\end{tabular}

Indexes refer to the results of Mann-Whitney $U$ tests for the comparison of CC plots and CF plots at each site

$H A S L$ height above sea level, $C_{o}$ organic carbon, $D O C$ dissolved organic carbon, $B S$ base saturation, $C E C_{\text {eff }}$ effective cation exchange capacity, ESS equilibrium soil solution, FS fine soil, $D W$ dry weight, $t$ total

(n.s. $P>0.05, * P \leq 0.05, * * P<0.01, * * * P<0.001$ )

${ }^{\mathrm{a}}$ See text

${ }^{\mathrm{b}}$ For site VI $\mathrm{C}_{\mathrm{t}} / \mathrm{N}$

of six cases appears a $\mathrm{pH}_{\mathrm{H} 2 \mathrm{O}}>7.0$. The $\mathrm{pH}_{\mathrm{KCl}}$ varied more strongly. $\mathrm{CC}$ soils exhibited values between 7.4 and 6.9. The $\mathrm{CF}$ soils fall into two groups: One group with $\mathrm{pH}_{\mathrm{KCl}}$ values $\leq 4.8$, and another group with $\mathrm{pH}$ values $\geq 6.2$.

Although the $\mathrm{C}_{\mathrm{o}} / \mathrm{N}$ ratios were generally very low, they were higher in the $\mathrm{CF}$ soils than in the $\mathrm{CC}$ soils, except for site $\mathrm{V}$. The concentrations of $\mathrm{NO}_{3}{ }^{-}$in the ESS of the CC plots always exceeded those of the corresponding CF plots, in median for all study sites 16-fold. Exceptionally high values for the CC plots at site IV and site VI, where soil samples were taken only once, can possibly be attributed to the high temporal variability of the microbial mineralization rate. Nevertheless, the $\mathrm{NO}_{3}{ }^{-}$concentrations in the plots were quite low, spanning a range of 0.2 to $427 \mathrm{nmol} \mathrm{g} \mathrm{DW}^{-1}$ (corresponding to 0.1 to $213.5 \mu \mathrm{M}$ measured in the ESS).

Several soil parameters were investigated only at the two main sites (Table 3). The CF soils contained less coarse material than the $\mathrm{CC}$ soils, and their fine soil density was higher. The volumetric water content $\Theta$, which was measured several times throughout the year, was always lower in the $\mathrm{CC}$ soils. The median $\Theta$ in the CF soils exceeded that of the CC plots by $71 \%$ (site I) and by $23 \%$ (site II), respectively. The lowest $\Theta(<15 \%)$ was found at site II after a 3 weeks of drought period in the middle of May (data not shown). However, similar or even lower extreme values are to be expected in the very shallow $\mathrm{CC}$ soil at site I.

The DOC in the ESS of the CC plots, which fall below the values of the $\mathrm{CF}$ plots, were in accordance with $C_{o}$ and $\Theta$ of the fine soil. Lower $C_{o}$ and higher DOC in the CF soils could be due to higher $\Theta$, favouring the microbial degradation of organic material. Based on differences between total and inorganic carbon, no $\mathrm{C}_{\mathrm{o}}$ could be calculated for the CC plot at site VI. Since the carbonate content of the fine soil at this site is very high, the organic carbon content may be masked by inaccuracy of the inorganic carbon measurement. 
The $\mathrm{CEC}_{\text {eff }}$ in the fine soils of the CF plots at site I and site II showed a tendency toward slightly lower values. However, the $\mathrm{CEC}_{\text {eff }}$ in the $\mathrm{CF}$ soils of site II was nearly equal to the $\mathrm{CEC}_{\text {eff }}$ of the $\mathrm{CC}$ soil at site I (Table 3). The base saturations of the $\mathrm{CC}$ plots exceeded only slightly, but significantly, the values of the CF plots.

Fe fractions and soil acidity

No seasonal trend of the $\mathrm{pH}$ or of the Fe concentration was observed in the ESS of the main sites in the course of the year (Fig. 1). The CF soil at site I exhibits a much more variable $\mathrm{pH}$ than the other soils, in accordance with its much lower $\mathrm{CaCO}_{3}$ content and, consequently, its lower buffering capacity. At the same time, the median $\mathrm{Fe}$ concentration of the fine soil in the CF plot at site I exceeds that of the CC soil by about $64 \%$, despite their nearly identical median $\mathrm{pH}$ values.

The $\mathrm{H}_{2} \mathrm{O}$ - and Ferrozine-extractable $\mathrm{Fe}$ contents, representing dissolved and easily soluble $\mathrm{Fe}$, generally indicate a higher plant Fe supply at a $\mathrm{CF}$ variant compared to the corresponding CC plot. The DTPA, NTA and oxalate extracts show similar patterns, except for two cases (Fig. 2).

Differences between the sites are similarly reflected by the various extracts: The $\mathrm{CF}$ soils of the sites I, IV and $\mathrm{V}$, characterised by low $\mathrm{pH}_{\mathrm{KCl}}$ values, generally exhibit relatively high $\mathrm{Fe}$ contents, except for the ESS of the CF soil at site I. The Ferrozine-, DTPA- and oxalate-extractable Fe fractions are strongly correlated with the $\mathrm{pH}_{\mathrm{KCl}}$ (Fig. 3; Table 4). The regressions show that the group of $\mathrm{CF}$ soils with $\mathrm{pH}_{\mathrm{KCl}}$ values $<4.8$ clearly contrasts with the $\mathrm{CC}$ soils and the group of $\mathrm{CF}$ soils with higher $\mathrm{pH}_{\mathrm{KCl}}$ values.

The water soluble $\mathrm{Fe}$ fraction deviates from the other fractions as it is more strongly correlated with the $\mathrm{pH}_{\mathrm{H} 2 \mathrm{O}}$ than with the $\mathrm{pH}_{\mathrm{KCl}}$ (Fig. 4; Table 4). In accordance with the known dependency of dissolved $\mathrm{Fe}$ (III) species from solution $\mathrm{pH}$, all soils in the $\mathrm{pH}_{\mathrm{H} 2 \mathrm{O}}$ range between 7.0 and 8.0 exhibited very low $\mathrm{Fe}_{\mathrm{H} 2 \mathrm{O}}$ contents, whereas the highest water soluble soil Fe content was found in the CF soil at site IV where the $\mathrm{pH}_{\mathrm{H} 2 \mathrm{O}}$ was lowest. At the study site I the median $\mathrm{pH}_{\mathrm{H} 2 \mathrm{O}}$ values of $7.4(\mathrm{CF})$ and $8.0(\mathrm{CC})$ correspond to an eightfold $\mathrm{Fe}$ concentration in the aqueous extracts of the CF soil.

\section{Phosphate fractions}

The sequential $\mathrm{P}$ extractions for the soils of the study sites I and II do not indicate a higher P availability in the CF plots (Fig. 5). Quite the reverse, the content of the easily accessible $\mathrm{P}_{\text {resin }}$ significantly exceeds that in the $\mathrm{CC}$ soils. The content of $\mathrm{NaHCO}_{3}$ extractable Olsen-P is higher in the $\mathrm{CF}$ soil at site I, but lower in the CF soil at site II. At both sites the sum of $\mathrm{P}_{\text {resin }}$ and $\mathrm{P}_{\mathrm{NaHCO}}$ in the $\mathrm{CC}$ soils tends to
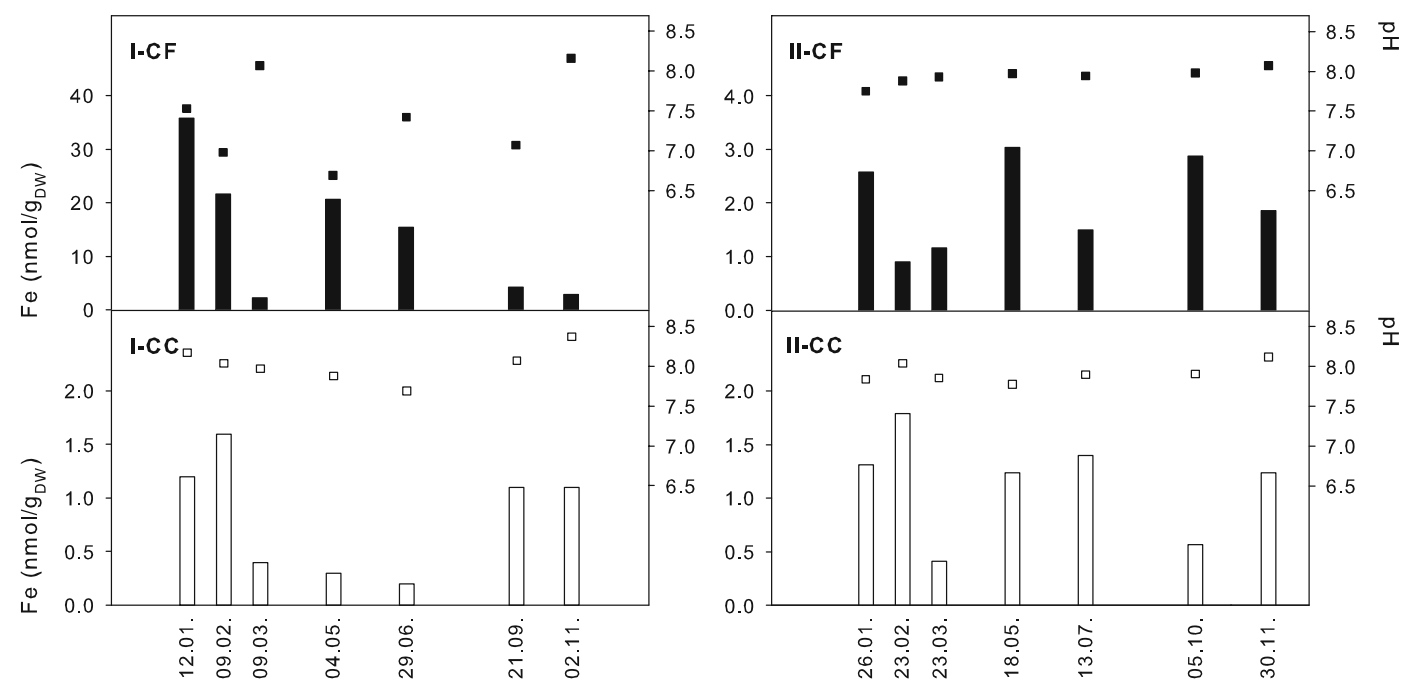

Fig. 1 Median Fe concentrations (nmol $\cdot \mathrm{g}_{\mathrm{DW}}^{-1}$; bars) and $\mathrm{pH}$ (square dots) of the ESS of CC soils (white) and CF soils (black) at study sites I and II over the course of the year $1998(n=8)$ 

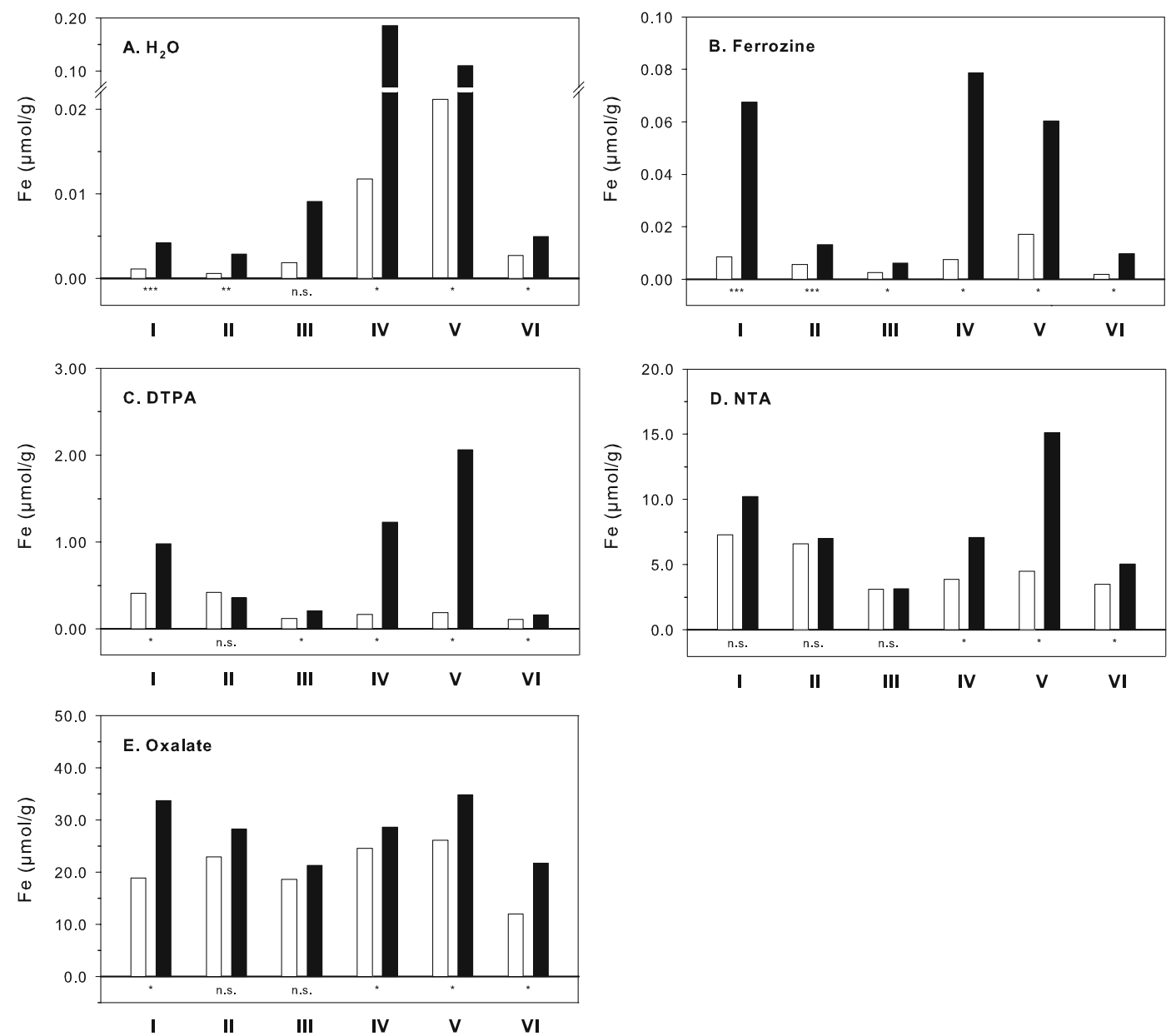

Fig. 2 Median $\mathrm{Fe}$ concentrations in fine soil material $\left(\mu \mathrm{mol} \mathrm{g}_{\mathrm{DW}}^{-1}\right)$ of $\mathrm{CC}$ plots (white bars) and CF plots (black bars) of the study sites I-VI extracted with $\mathrm{H}_{2} \mathrm{O}$, Ferrozine, DTPA, NTA and sodium oxalate/oxalic acid. Indexes refer to the

exceed the content of these fractions in the CF soils. The contents of the less easily accessible $\mathrm{NaOH}-$ extractable fraction was higher in the CF soil at site I but not at site II, and the contents of the HCl-soluble fraction was considerably lower at both sites in the $\mathrm{CF}$ soils than in the $\mathrm{CC}$ soils.

As a result, a comparison of $\mathrm{CF}$ soils and $\mathrm{CC}$ soils at the supplementary sites was restricted to the $\mathrm{P}$ concentrations of the ESS. These concentrations were only significantly higher in CF soil than in $\mathrm{CC}$ soil at site IV, whereas at the other sites no significant concentration differences were found (Fig. 6). Again, the $\mathrm{P}$ contents of $\mathrm{CF}$ soils at some sites were lower than the contents of $\mathrm{CC}$ soils at other sites.

results of Mann-Whitney $U$ tests for comparisons of CC plots and $\mathrm{CF}$ plots at each site $\left(n=4, n=8\right.$ for $\mathrm{H}_{2} \mathrm{O}$ and Ferrozine extracts from sites I-II; n.s. $P>0.05, * P \leq 0.05, * * * P<0.01, P<$ $0.001)$

\section{Discussion}

Quantification of plant-available Fe and P in calcareous soils

The Fe pool in the soil includes a multitude of solid and dissolved inorganic and organic fractions of ferric and ferrous iron. Hydrolysis of $\mathrm{Fe}$ oxides, $\mathrm{Fe}$ hydroxides and $\mathrm{Fe}$ oxyhydroxides (denoted here as $\mathrm{Fe}$ (oxy/hydr)oxides), chelation of $\mathrm{Fe}^{3+}$, as well as reductive mobilisation and reoxidation of $\mathrm{Fe}^{2+}$ depend on the soil $\mathrm{pH}$. Thus, soil acidity is the key factor determining $\mathrm{Fe}$ speciation and, therefore, the $\mathrm{Fe}$ solubility in the soil. In principle, $\mathrm{Fe}$ solubility is minimal around a $\mathrm{pH}$ of 8 , i.e. within the buffer range 

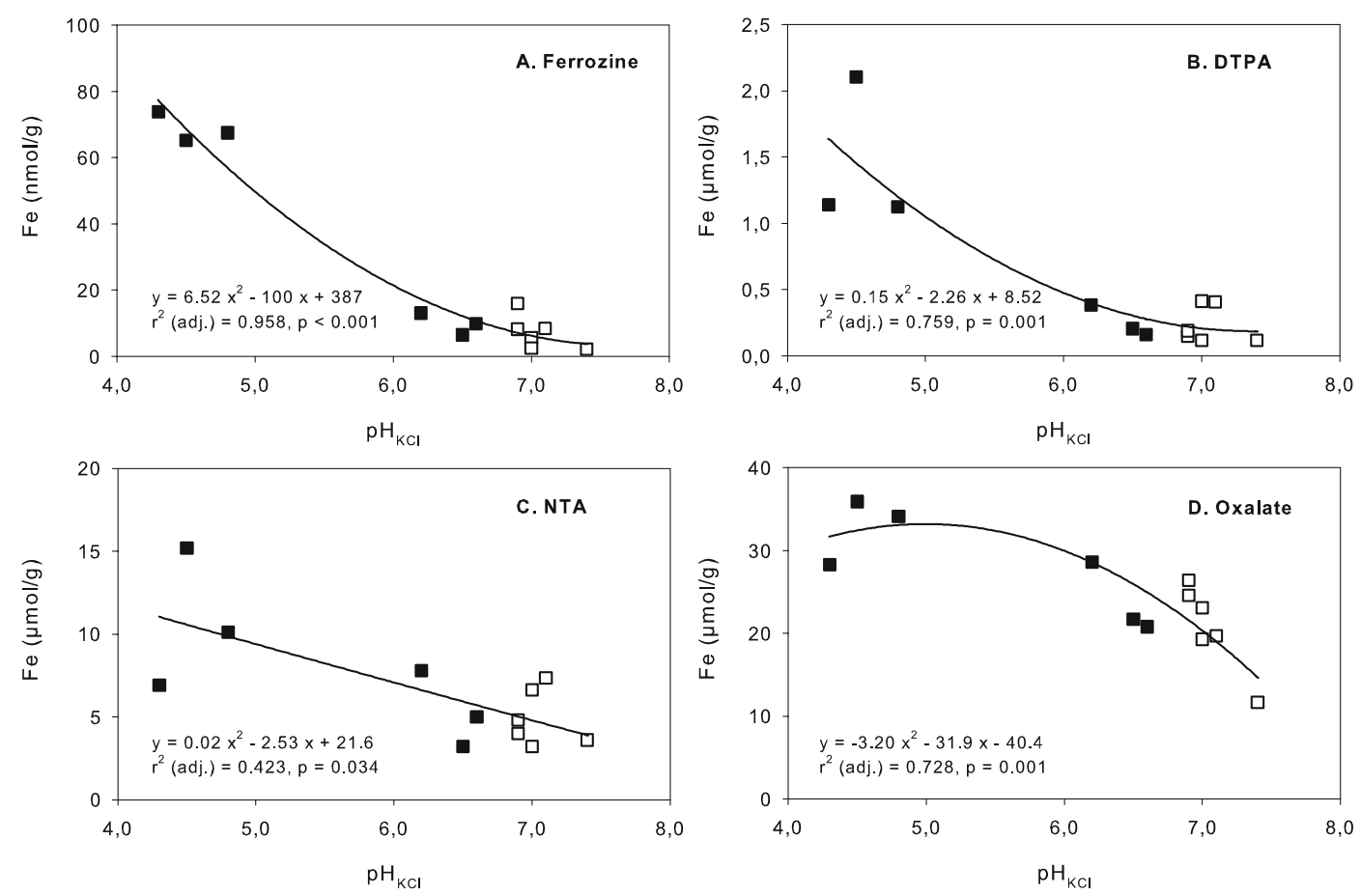

Fig. 3 Dependency of different $\mathrm{Fe}$ fractions on $\mathrm{pH}_{\mathrm{KCl}}$ in fine soils of CC plots (white symbols) and CF plots (black symbols) of the study sites I-VI

of calcareous soils, and increases with decreasing $\mathrm{pH}$. However, depending on the texture and water content of the soil, the microbial activity and the redox potential, the quality and quantity of inorganic and organic material (i.e. the concentration of $\mathrm{Fe}$ complexing compound) can vary, causing different $\mathrm{Fe}$ solubilities at a given $\mathrm{pH}$.

The general $\mathrm{pH}$ dependency of Fe solubility is reflected by the results of our investigations of the ESS (Fig. 4; Table 4). When the results of all $\mathrm{Fe}$ analyses are plotted against the $\mathrm{pH}$ (Fig. 7), the course

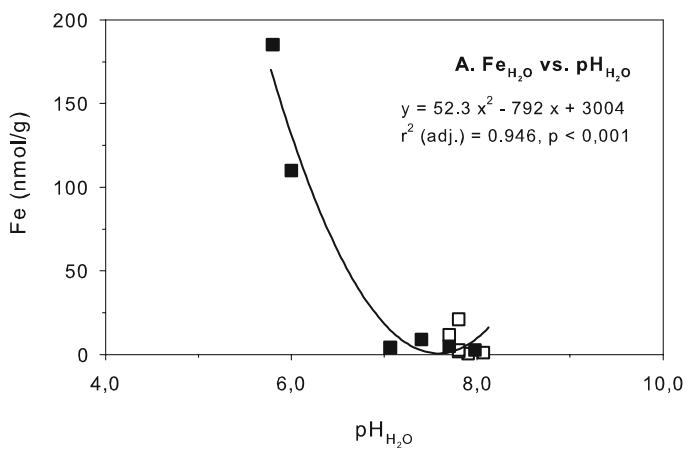

of the regression function is in principal similar to that presented by Lindsay (1979) for inorganic ferric iron. However, since these extracts contain also $\mathrm{Fe}^{2+}$ and organic Fe-complexes, the mean Fe concentrations in the ESS are higher.

In contrast to $\mathrm{Fe}_{\mathrm{H} 2 \mathrm{O}}$, which depends primarily on the $\mathrm{pH}_{\mathrm{H} 2 \mathrm{O}}$, the other $\mathrm{Fe}$ fractions show a stronger correlation with $\mathrm{pH}_{\mathrm{KCl}}$ (Fig. 3; Table 4). This is plausible because they result ultimately from the $\mathrm{pH}$ dependent weathering of $\mathrm{Fe}$ minerals, and because the $\mathrm{pH}_{\mathrm{KCl}}$ reflects the maximal acidity that occurred

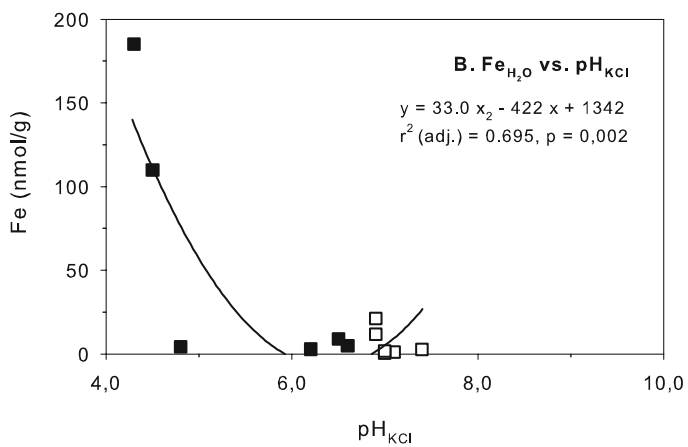

Fig. 4 Dependency of $\mathrm{Fe}_{\mathrm{H} 2 \mathrm{O}}$ on $\mathrm{pH}_{\mathrm{H} 2 \mathrm{O}}$ and $\mathrm{pH}_{\mathrm{KCl}}$ in fine soils of CC plots (white symbols) and CF plots (black symbols) of the study sites I-VI 
Table 4 Adjusted coefficients of determination $\left(r_{\text {adj. }}^{2}\right)$ for linear regressions of $\mathrm{pH}_{\mathrm{H} 2 \mathrm{O}} \mathrm{vs}$. $\mathrm{pH}_{\mathrm{KCl}}$ and for quadratic regressions of Fe fractions, respectively

\begin{tabular}{|c|c|c|c|c|c|c|}
\hline & $\mathrm{pH}_{\mathrm{H} 2 \mathrm{O}}$ & $\mathrm{pH}_{\mathrm{KCl}}$ & $\mathrm{Fe}_{\mathrm{H} 2 \mathrm{O}}$ & $\mathrm{Fe}_{\mathrm{Ferro}}$ & $\mathrm{Fe}_{\text {DTPA }}$ & $\mathrm{Fe}_{\mathrm{NTP}}$ \\
\hline $\mathrm{pH}_{\mathrm{KCl}}$ & $0.808 * * *$ & - & - & - & - & - \\
\hline $\mathrm{Fe}_{\mathrm{H} 2 \mathrm{O}}$ & $0.946 * * *$ & $0.695 * * *$ & - & - & - & - \\
\hline $\mathrm{Fe}_{\mathrm{Ferro}}$ & $0.760 * * *$ & $0.958 * * *$ & $0.540 * *$ & - & - & - \\
\hline $\mathrm{Fe}_{\mathrm{DTPA}}$ & $0.652 * *$ & $0.759 * * *$ & $0.416^{\text {n.s. }}$ & $0.751 * * *$ & - & - \\
\hline $\mathrm{Fe}_{\mathrm{NTA}}$ & $0.210^{\text {n.s. }}$ & $0.423^{*}$ & $0.101^{\text {n.s. }}$ & $0.479 * *$ & $0.835^{* * *}$ & - \\
\hline $\mathrm{Fe}_{\text {Oxal }}$ & $0.268^{\text {n.s. }}$ & $0.728 * * *$ & $0.131^{\text {n.s. }}$ & $0.576^{* *}$ & $0.571 * *$ & $0.583 * *$ \\
\hline
\end{tabular}

The data refer to analyses of field-moist fine soil homogenates from all investigation sites

(n.s. $P>0.05, * P \leq 0.05, * * P<0.01, * * * \mathrm{P}<0.001$ )

during the course of weathering in these soils (Ulrich 1986).

Similarly to $\mathrm{Fe}$, the speciation of $\mathrm{P}$ in the soil is primarily a function of $\mathrm{pH}$ (Lindsay et al. 1989). However, plant $\mathrm{P}$ availability is much less correlated with the $\mathrm{pH}$ and $\mathrm{CaCO}_{3}$ content of the soil. The precipitation of $\mathrm{Ca}$ phosphates and the formation of apatites is promoted by high $\mathrm{pH}$ and $\mathrm{Ca}^{2+}$ concentrations, whereas orthophosphate anions can be desorbed from exchange sites of inorganic and organic soil constituents by the high activities of $\mathrm{OH}^{-}$and $\mathrm{HCO}_{3}{ }^{-}$typical for calcareous soils (Hinsinger 2001). Accordingly, we measured higher mean $\mathrm{P}_{\mathrm{H} 2 \mathrm{O}}$ contents in $\mathrm{CC}$ soils despite higher $\mathrm{pH}$ than in $\mathrm{CF}$ soils (Fig. 5).

Does Fe and/or P nutrition affect the occurrence of $C$. vulgaris in semi-arid calcareous grasslands?

At each individual site, the $\mathrm{Fe}_{\mathrm{H} 2 \mathrm{O}}$ content of the $\mathrm{CF}$ soil is higher than that of the corresponding CC soil.
However, a comparison between the study sites reveals that the upper $\mathrm{pH}$ ranges of $\mathrm{CF}$ soils and $\mathrm{CC}$ soils overlap to a great degree (Table 3 ), and that the Fe solubility in some CC plots exceeds that in the CF plots at other sites (Fig. 2).

When using Ferrozine as extractant, not only dissolved but also adsorbed and weakly bound $\mathrm{Fe}^{2+}$ ions are determined (Fühner 2005). $\mathrm{Fe}_{\mathrm{Ferro}}$ is only loosely correlated with the $\mathrm{Fe}_{\mathrm{H} 2 \mathrm{O}}\left(R^{2}=0.540\right.$; Table 4). Nevertheless, it shows a similar distribution pattern: At each site the $\mathrm{Fe}_{\mathrm{Ferro}}$ content of the CF plot exceeds that of the corresponding $\mathrm{CC}$ plot, but at some sites the CC soils show higher contents of $\mathrm{Fe}_{\text {Ferro }}$ than the CF soils at other sites (Fig. 2). The same applies to the fractions of $\mathrm{Fe}_{\mathrm{DTPA}}, \mathrm{Fe}_{\mathrm{NTA}}$ and $\mathrm{Fe}_{\text {Oxal }}$. Thus, the analyses of all Fe fractions in fieldmoist fine soil do not support the hypothesis that a higher Fe supply enables $C$. vulgaris and other calcifuge plant species to grow in calcareous grasslands.

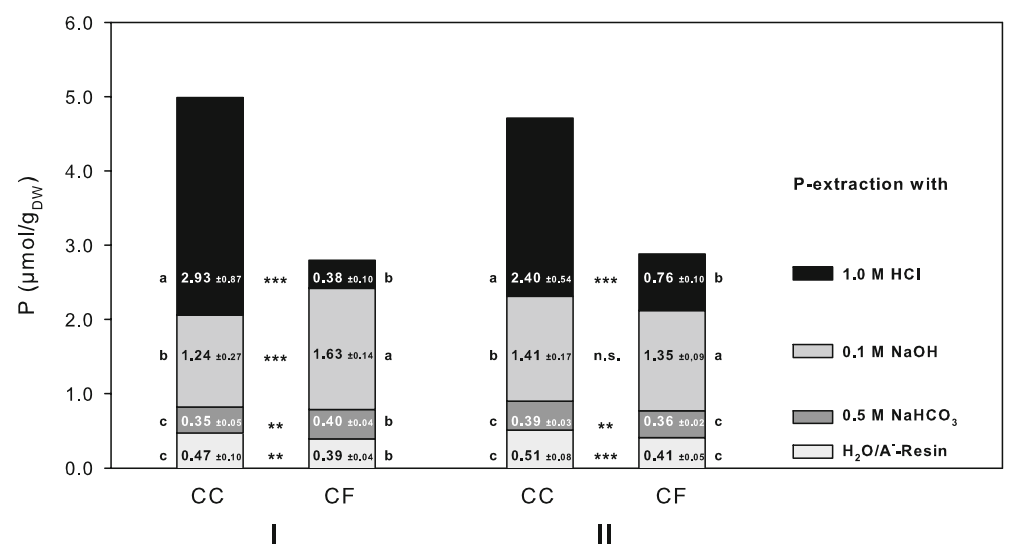

Fig. $5 \mathrm{P}$ fractions $\left(\mu \mathrm{mol} \mathrm{g}_{\mathrm{DW}}^{-1}\right)$ determined by sequential $\mathrm{P}$ analyses of air-dry fine soil from CC plots and CF plots at study sites I and II (means $\pm \mathrm{SD}, n=16$ ). Indexes refer to the results of
Student-t-tests for site-specific $\mathrm{CC} / \mathrm{CF}$ comparisons (n.s. $P>$ $0.05, * * P<0.01, * * * P<0.01, P<0.001)$ 


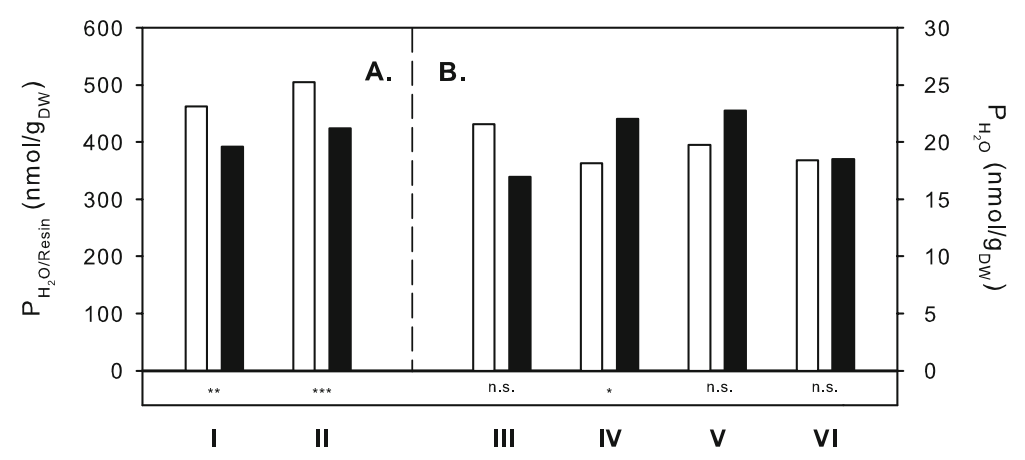

Fig. 6 Mean $\mathrm{P}$ concentrations $\left(\mu \mathrm{mol} \mathrm{g}_{\mathrm{DW}}^{-1}\right)$ of aqueous extractions of CC soils (white bars) and CF soils (black bars) of study sites I-VI. a Extracts from air-dry ground soil, using $\mathrm{H}_{2} \mathrm{O}$ and anion exchanger resin $(n=16)$. b ESS from field-moist

No indications of a higher $\mathrm{P}$ availability in the $\mathrm{CF}$ soils compared to the $\mathrm{CC}$ soils were found. On the contrary, the $\mathrm{P}_{\text {resin }}$ contents, characterising the most easily available fraction, indicate a higher availability in the $\mathrm{CC}$ soils of the extensively investigated main sites I and II (Fig. 5). The $\mathrm{P}_{\mathrm{NaHCO} 3}$ contents and the $\mathrm{P}_{\mathrm{NaOH}}$ contents exhibit a non-uniform distribution, and the $\mathrm{P}_{\mathrm{HCl}}$ contents, characterising a fraction which would become available in the long term due to weathering, are much higher in the $\mathrm{CC}$ soils. The differences between the $\mathrm{P}$ contents in the ESS of the CC soils and CF soils at the supplementary sites III to VI are inconsistent and for the most part insignificant (Fig. 6). They do not provide an argument for a decisive role of $\mathrm{P}$ availability in the spatial distribution of $C$. vulgaris and the moderately calcifuge sieved soil $(n=4)$. Indexes refer to the results of Mann-Whitney $U$ tests $\mathrm{CC}$ vs. CF (n.s. $P>0.05$, ${ }^{*} P=0.050, * * P=0.010$, $* * * P<$ $0.001)$

species at the study sites. Thus, the primary hypothesis that the distribution of $C$. vulgaris and other calcifuge plant species in calcareous grasslands is influenced by the $\mathrm{P}$ supply is not supported by the results.

Secondary effects on plant Fe and $\mathrm{P}$ nutrition at the study sites

Even if the contents of the investigated $\mathrm{Fe}$ and $\mathrm{P}$ fractions do not differ substantially between CC soils and $\mathrm{CF}$ soils, interferences with other soil properties could result in different availabilities of these nutrients. Properties which are always higher in $\mathrm{CC}$ soils than in $\mathrm{CF}$ soils are the $\mathrm{CaCO}_{3}$ and the $\mathrm{NO}_{3}{ }^{-}$ contents, whereas, as measured at the main sites, the

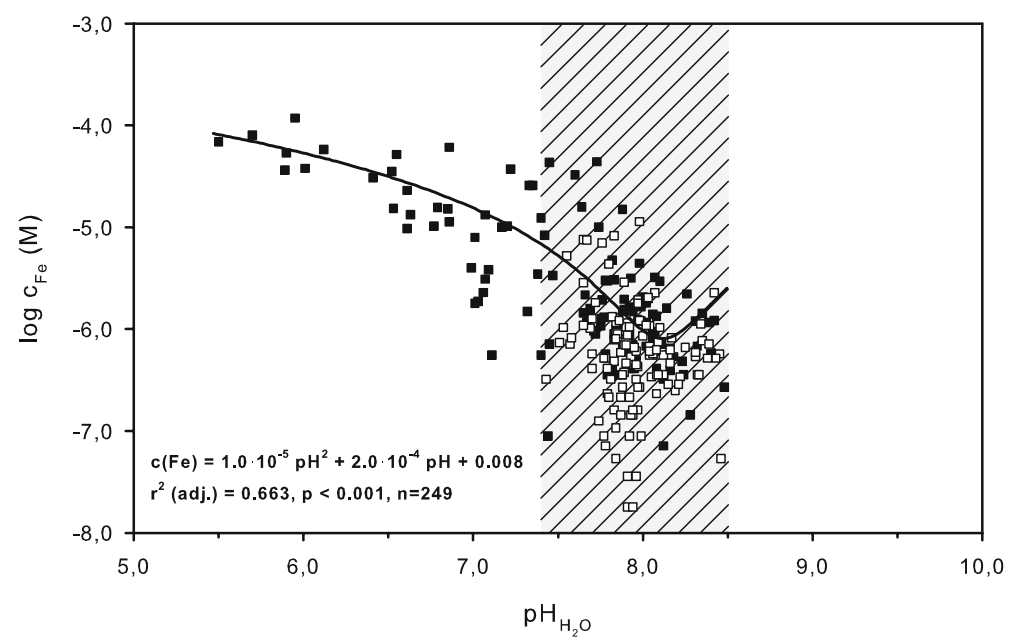

Fig. 7 Non-linear regression for $\log c\left(\mathrm{Fe}_{\mathrm{H} 2 \mathrm{O}}\right)$ vs. $\mathrm{pH}_{\mathrm{H} 2 \mathrm{O}}$ based on all measurements in ESS of CC soils (white symbols) and $\mathrm{CF}$ soils (black symbols). Hatching indicates the $\mathrm{pH}$ range of minimal solubility of inorganic Fe(III) species according to Lindsay (1979) 
volumetric water contents and the soil densities are lower (Table 3).

Higher moisture and higher density reduce soil aeration and can thus increase the reductive formation of dissolved $\mathrm{Fe}^{2+}$. Moreover, higher soil moisture can favour microbial activity and, thus, the dissolution of $\mathrm{Fe}(\mathrm{III})$ by organic ligands in $\mathrm{CF}$ soils compared to $\mathrm{CC}$ soils of similar $\mathrm{pH}$ (Fig. 7). Contrary physical conditions in $\mathrm{CC}$ soils could reduce the formation of plant available Fe by inhibiting microbial activity, as indicated by the lower DOC and higher $\mathrm{C}_{\mathrm{o}}$ contents (Table 3). However, in view of the fact that the contents of the various $\mathrm{Fe}$ fractions are higher in some CC soils than in some CF soils, this cannot be of general significance for the occurrence of calcifuges at the sites investigated.

In systems saturated with calcite the $\mathrm{HCO}_{3}{ }^{-}$ concentration is positively and the $\mathrm{pH}$ negatively correlated with the partial pressure of $\mathrm{CO}_{2}$ (Loeppert 1988). Consequently, plant and microbial respiration can result in a drop of the $\mathrm{pH}$ and, in the process, enhanced dissociation of Fe-(oxy/hydr)oxides in the rhizosphere of plants on calcareous soils. Moreover, $\mathrm{Fe}(\mathrm{III})$ reduction and formation of organic Fe complexes could be favoured, additionally improving the Fe supply to the plants. However, negative effects could result from the production of $\mathrm{HCO}_{3}{ }^{-}$in the course of $\mathrm{CaCO}_{3}$ dissolution. $\mathrm{HCO}_{3}{ }^{-}$can reach high concentrations, especially, if the gas exchange is reduced by higher densities and/or moisture contents of the soil (e.g. Misra and Tyler 1999). Since $\mathrm{HCO}_{3}{ }^{-}$ in combination with its buffering capacity to neutral or slightly alkaline $\mathrm{pH}$ interferes with external and internal mechanisms of $\mathrm{Fe}$ acquisition in several ways (Doney et al. 1960; Lee and Woolhouse 1969b; Toulon et al. 1992; Mengel 1994, Romera et al. 1997; Römheld 2000), it could, theoretically, result in a reduced Fe supply to plants in $\mathrm{CaCO}_{3}$-rich $\mathrm{CC}$ soils compared to $\mathrm{CaCO}_{3}$-poorer $\mathrm{CF}$ soils, even at similar soluble Fe contents. Our investigations do not allow a definite decision as to whether such $\mathrm{HCO}_{3}{ }^{-}$effects play a role in the exclusion of $C$. vulgaris and the moderately calcifuge species from the CC soils. Lee and Woolhouse (1971) have shown that selected calcifuge species are more susceptible to $\mathrm{HCO}_{3}{ }^{-}$than the calcicole species selected for comparison. Leake et al. (1990) found that C. vulgaris with Hymenoscyphus ericae as mycorrhizal fungus suffers from decreasing Fe uptake in nutrient solutions at $\mathrm{pH} 7.0$ when the $\mathrm{CO}_{3}{ }^{2-}$ concentrations exceed $2.5 \mathrm{mM}$. But, special studies into the effects of realistic $\mathrm{HCO}_{3}{ }^{-}$ concentrations on this species have not yet been performed.

The $\mathrm{CaCO}_{3}$ contents of $\mathrm{CF}$ soils are still sufficient to keep the $\mathrm{pH}$ within the carbonate-buffer range. Concurrently, the higher density as well as the higher mean moisture content could favour the enrichment of $\mathrm{HCO}_{3}{ }^{-}$in $\mathrm{CF}$ soils. As a consequence, it seems unlikely that $\mathrm{HCO}_{3}{ }^{-}$affects the $\mathrm{Fe}$ supply to $C$. vulgaris in $\mathrm{CF}$ soils less than in CC soils. Thus, $\mathrm{HCO}_{3}{ }^{-}$is probably not decisive for the species' exclusion from the $\mathrm{CC}$ plots.

In addition to $\mathrm{HCO}_{3}{ }^{-}, \mathrm{NO}_{3}{ }^{-}$is also known to interfere with the $\mathrm{Fe}$ utilisation of plants (Mengel 1994). Theoretically, this could be another factor that prevents calcifuge species from growing in CC soils as higher concentrations were always found in those soils than in CF soils. However, apart from the fact that the existence of a higher susceptibility to $\mathrm{NO}_{3}{ }^{-}$in calcifuge species than in calcicole ones has not yet been established, such an effect is improbable because the absolute $\mathrm{NO}_{3}{ }^{-}$concentrations in the soil extracts were always in a nanomolar to micromolar range, whereas detrimental effects were established in nutrient solutions with $\mathrm{NO}_{3}{ }^{-}$concentrations in the millimolar range.

Effects of $\mathrm{HCO}_{3}{ }^{-}$and $\mathrm{NO}_{3}{ }^{-}$on the uptake and utilisation of $\mathrm{P}$ are not known. Theoretically, anions could improve $\mathrm{P}$ availability due to the desorption of phosphates from anion exchangers, and higher soil moisture could improve the diffusive translocation of $P$ to the root surface (Hinsinger 2001). These processes would favour the plant $\mathrm{P}$ supply in $\mathrm{CF}$ soils. But their practical significance in the case of $C$. vulgaris is doubtful because this species' $\mathrm{P}$ acquisition is supported by the associated mycorrhiza and the network of mycelial hyphae in the soil that diminishes the relative importance of a diffusive translocation.

Therefore, an exclusion of $C$. vulgaris from the investigated calcareous soils by $\mathrm{Fe}$ or $\mathrm{P}$ deficiency appears rather improbable, even if secondary effects are considered.

A scenario of the connections between topography, pedogenesis and the occurrence of $C$. vulgaris

The CF plots differ from the CC plots by a lower slope and/or a more northerly exposition (Table 3). 
Consequences of these characteristics, such as lower insolation and probably lower surface run-off and higher soil moisture, have led to a more intense weathering and, thus, to the deeper solum, to the lower contents of $\mathrm{CaCO}_{3}$ and $\mathrm{HCl}$-extractable $\mathrm{P}$, and, at the level of individual sites, to the higher actual and particularly higher potential acidity of the CF soils. A lower evaporative demand and a more continuous soil water availability may have favoured the establishment of C. vulgaris, whereas contrary conditions at $\mathrm{CC}$ plots may have prevented moisture-demanding seed germination (Pons 1989) and the establishment of the species' seedlings, which are very susceptible to drought (Gimingham 1960). Once established, $C$. vulgaris may have accelerated soil acidification and may have contributed to the phenomenon that unusually low $\mathrm{pH}$ values, reflected by potential soil acidities down to $\mathrm{pH}_{\mathrm{KCl}} 4.3$ were temporarily reached in these soils (Ulrich 1986) despite the originally high $\mathrm{CaCO}_{3}$ contents. The soil-acidifying effect of $C$. vulgaris is a well known phenomenon (Grubb et al. 1969; Grubb and Suter 1971).

The current degree of coverage of this species appears insufficient to produce soil acidification down to $\mathrm{pH}$ 4.3. However, according to oral information from the local shepherd and the nature conservation representative, the CF plots at sites I and II had a closed and high $C$. vulgaris cover in former times. In the second half of the last century the cover of $C$. vulgaris at the study sites declined continuously, coinciding with a decrease in grazing intensity and a simultaneous increase of aerial $\mathrm{N}$ input as well as increasing competition from upcoming bushes, which are now removed periodically by public conservation actions. Competition from grasses and bushes, promoted by atmospheric $\mathrm{N}$ deposition, is probably the main cause of the still ongoing decline of $C$. vulgaris. Increased drought sensitivity as a consequence of high N supply (Gordon et al. 1999) could be additionally involved. Controlled burning as used in heathland management on acid soils and moorland under more oceanic climates in order to reduce ecosystem $\mathrm{N}$ pool and $\mathrm{N}$ turnover (e.g. Nilsen et al. 2005; Pilkington et al. 2007), was not applied at our study sites. Damages to $C$. vulgaris through detrimental effects of the increased $\mathrm{N}$ supply on its ericoid mycorrhiza is unlikely because Johansson (2000) found no effects of fertilizations as high as $70 \mathrm{~kg} \mathrm{~N}$ $\mathrm{ha}^{-1}$ year $^{-1}$ in the form of ammonium nitrate.
Inhibition of ericoid mycorrhizal infection of $C$. vulgaris roots in moorland peat by ammonium sulphate and nitric acid fertilization, observed by Yesmin et al. (1996), were due to simultaneous soil acidification and are not relevant at the sites investigated here.

Under the current conditions, buffering processes obviously exceed acidifying processes in the $\mathrm{CF}$ plots, resulting in a $\mathrm{pH}_{\mathrm{H} 2 \mathrm{O}}$ well above the $\mathrm{pH}_{\mathrm{KCl}}$. But the latter provides evidence of much stronger acidification of the CF soils in the past, exceeding the buffering rate for a long time (Ulrich 1986). Since this is most probably an effect of $C$. vulgaris, the causal chain of our initial hypothesis becomes reversed: Higher soil acidity and higher Fe availability are consequences of and not preconditions for the establishment of $C$. vulgaris, at least in the semi-arid calcareous grasslands of the main sites. But, a similar development can be assumed at the other CF plots.

We assume, therefore, that local moisture conditions were decisive for the initial establishment of $C$. vulgaris and that weathering remained much weaker at the $\mathrm{CC}$ plots because the establishment of $C$. vulgaris was prevented there by drought. The establishment of other moderately calcifuge species in the $\mathrm{CF}$ plots could then be favoured by the soil acidifying effect of C. vulgaris.

In the present state, $C$. vulgaris occurs at our study sites on soils with $\mathrm{pH}_{\mathrm{H} 2 \mathrm{O}}$ values up to 7.9 and with $\mathrm{pH}_{\mathrm{KCl}}$ values up to 6.6. Correspondingly, the base saturation of CF soils amounts to $99.5 \%$. Its growth under these conditions emphasises that the calcifuge distribution of this species is not caused by a physiological inability to cope with high $\mathrm{pH}$ and high Ca contents of the substrate. Apparently, C. vulgaris, regarded as a strictly calcifuge species and given the reaction value 1 by Ellenberg et al. (1992), is able to grow on calcareous soils with high $\mathrm{pH}$ values, even if the species has its main occurrence on Ca-poor and very acidic soils. Therefore, the reaction value 1 (strong acidity indicator, never occurring on slightly acid to alkaline soils) does not appear to be appropriate.

Acknowledgments We would like to thank Magdolna Weller and Simone Klatt for excellent technical assistance. Thanks are also due to Dirk Gries and two anonymous reviewers for helpful comments on the manuscript. This work was supported by a grant from the Deutsche Forschungsgemeinschaft (Ru 136/ $10-1,10-2)$. 
Open Access This article is distributed under the terms of the Creative Commons Attribution Noncommercial License which permits any noncommercial use, distribution, and reproduction in any medium, provided the original author(s) and source are credited.

\section{References}

Borggaard OK (1988) Phase identification by selective dissolution techniques. In: Stucki JW, Goodman BA, Schwertmann U (eds) Iron in soils and clay minerals. Reidel, Dordrecht, pp 83-98

Campbell AS, Schwertmann U (1984) Iron oxide mineralogy of placic horizons. J Soil Sci 35:569-582 doi:10.1111/j.13652389.1984.tb00614.x

Doney RC, Smith RL, Wiebe HH (1960) Effects of various levels of bicarbonate, phosphorus and $\mathrm{pH}$ on the translocation of foliar-applied iron in plants. Soil Sci 89:269-275 doi:10.1097/00010694-196005000-00007

Dušek L (1995) The effect of cadmium on the activity of nitrifying populations in two different grassland soils. Plant Soil 177:43-53 doi:10.1007/BF00010336

Ellenberg H, Weber HE, Düll R, Wirth V, Werner W, Paulissen D (1992) Zeigerwerte von Pflanzen in Mitteleuropa, 2nd edn. Goltze, Göttingen

Falkengren-Grerup U, Quist ME, Tyler G (1995) Relative importance of exchangeable and soil solution cation concentrations to the distribution of vascular plants. Environ Exp Bot 35:9-15 doi:10.1016/0098-8472(94) 00039-8

FAO (2006) World Reference Base for soil resources (WRB), Resources Reports 103. FAO, Rome

Fühner C (2005) Das Auftreten acidophiler/calcifuger Pflanzenarten in Kalk-Halbtrockenrasen. PhD thesis, University of Göttingen, Dep. Ecology and Ecosystems Research

Gimingham CH (1960) Biological flora of the British isles: Calluna vulgaris (L.) HULL. J Ecol 48:455-483 doi: $10.2307 / 2257528$

Gordon C, Woodin SJ, Alexander IJ, Mullins CE (1999) Effects of increased temperature, drought and nitrogen supply on two upland perennials of contrasting functional type: Calluna vulgaris and Pteridium aquilinum. New Phytol 142:243-258 doi:10.1046/j.1469-8137.1999.00399.x

Gries D, Runge M (1995) Responses of calcicole and calcifuge Poaceae species to iron limiting conditions. Bot Acta 108:482-489

Grime JP (1963) Factors determining the occurrence of calcifuge species on shallow soils over calcareous substrata. J Ecol 51:375-390 doi:10.2307/2257691

Grime JP, Hodgson JG (1969) An investigation of the ecological significance of lime-chlorosis by means of large-scale comparative experiments. In: Rorison RH (ed) Ecological aspects of the mineral nutrition of plants. Blackwell, Oxford, pp 67-99

Grubb PJ, Suter MB (1971) The mechanism of soil acidification by Calluna and Ulex and the significance for conservation. In: Duffey E, Watt AS (eds) The scientific management of plant and animal communities for conservation. Blackwell, Oxford, pp 115-133
Grubb PJ, Green HE, Merrifield RCJ (1969) The ecology of chalk heath: its relevance to the calcicole-calcifuge and soil acidification problems. J Ecol 57:175-212 doi:10. $2307 / 2258215$

Hinsinger P (2001) Bioavailability of soil inorganic P in the rhizosphere as affected by root-induced chemical changes: a review. Plant Soil 237:173-195 doi:10.1023/A: 1013351617532

Johansson M (2000) The influence of ammonium nitrate on the root growth and ericoid mycorrhizal colonization of Calluna vulgaris (L.) Hull from a Danish heathland. Oecologia 123:418-424 doi:10.1007/s004420051029

Koperski M, Sauer M, Braun W, Gradstein SR (2000) Referenzliste der Moose Deutschlands. Landwirtschaftsverlag, Münster

Kosegarten HU, Hoffmann B, Mengel K (1999) Apoplastic pH and $\mathrm{Fe}^{3+}$ reduction in intact sunflower leaves. Plant Physiol 121:1069-1079 doi:10.1104/pp.121.4.1069

Leake JR, Shaw G, Read DJ (1990) The biology of mycorrhiza in the Ericaceae-XVI. Mycorrhiza and iron uptake in Calluna vulgaris (L.) Hull in the presence of two calcium salts. New Phytol 114:651-657 doi:10.1111/j.14698137.1990.tb00436.x

Lee JA, Woolhouse HW (1969a) A comparative study of bicarbonate inhibition of root growth in calcicole and calcifuge grasses. New Phytol 68:1-11 doi:10.1111/ j.1469-8137.1969.tb06413.x

Lee JA, Woolhouse HW (1969b) Root growth and dark fixation of carbon dioxide in calcicoles and calcifuges. New Phytol 68:247-255 doi:10.1111/j.1469-8137.1969.tb06437.x

Lee JA, Woolhouse HW (1971) The relationship of compartmentation of organic acid metabolism to bicarbonate ion sensitivity of root growth in calcicoles and calcifuges. New Phytol 70:103-111 doi:10.1111/j.1469-8137.1971.tb02515.x

Lindsay WL (1979) Chemical equilibria in soils. Wiley, New York

Lindsay WL, Norvell WA (1978) Development of a DTPA soil test for zinc, iron, manganese, and copper. Soil Sci Soc Am J 42:421-428

Lindsay WL, Vlek PLG, Chien SH (1989) Phosphate minerals. In: Dixon JB, Weed SB (eds) Minerals in soil environment. Soil Science Society of America, Madison, pp 1089-1130

Loeppert RH (1988) Chemistry of iron in calcareous systems. In: Stucki JW, Goodman BA, Schwertmann U (eds) Iron in soils and clay minerals. Reidel, Dordrecht, pp 689-713

Loeppert RH, Suarez DL (1996) Carbonate and gypsum. In: Sparks DL, Page AL, Helmke PA, Loeppert RH, Soltanpour PN, Tabatabai MA, Johnson CT, Sumner ME (eds) Methods of soil analysis. Part 3: Chemical methods. SSSA Special Publication No. 5, Soil Science Society of America, Madison, pp 437-475

Ludwig B, Meiwes KJ, Khanna P, Gehlen R, Fortmann H, Hildebrand EE (1999) Comparison of different laboratory methods with lysimetry for soil solution compositionexperimental and model results. J Plant Nutr Soil Sci 162:343-351 doi:10.1002/(SICI)1522-2624(199906) 162:3<343::AID-JPLN343>3.0.CO;2-E

Mengel K (1994) Iron availability in plant tissues-iron chlorosis on calcareous soils. Plant Soil 165:275-283 doi:10.1007/BF00008070 
Misra A, Tyler G (1999) Influence of soil moisture on soil solution chemistry and concentrations of minerals in the calcicoles Phleum phleoides and Veronica spicata grown on a limestone soil. Ann Bot (Lond) 84:401-410 doi:10.1006/anbo.1999.0941

Murphy J, Riley JP (1962) A modified single solution method for the determination of phosphate in natural waters. Anal Chim Acta 27:31-36 doi:10.1016/S00032670(00)88444-5

Niklaus PA (1998) Soil microbial effects of elevated $\mathrm{CO}_{2}$ in calcareous grassland. Glob Chang Biol 4:451-458 doi:10.1046/j.1365-2486.1998.00166.x

Niklaus PA, Falloon P (2006) Estimating soil carbon sequestration under elevated $\mathrm{CO}_{2}$ by combining carbon isotope labelling with soil carbon cycle modelling. Glob Chang Biol 12:1909-1921 doi:10.1111/j.13652486.2006.01215.x

Nilsen LS, Johansen L, Velle LG (2005) Early stages of Calluna vulgaris regeneration after burning of coastal heath in central Norway. Appl Veg Sci 8:57-64 doi:10.1658/14022001(2005)008[0057:ESOCVR]2.0.CO;2

Pilkington MG, Caporn SJM, Carroll JA, Cresswell N, Phoenix GK, Lee JA et al (2007) Impacts of burning and increased nitrogen deposition on nitrogen pools and leaching in an upland moor. J Ecol 95:1195-1207 doi:10.1111/j.1365-2745.2007.01292.x

Pons TL (1989) Dormancy, germination and mortality of seeds in heathland and inland sand dunes. Acta Bot Neerl 38:327-336

Romera FJ, Alcantara E, de la Guardia MD (1997) Influence of bicarbonate and metal ions on the development of root Fe (III) reducing capacity by Fe-deficient cucumber (Cucumis sativus) plants. Physiol Plant 101:143-148 doi:10.1111/ j.1399-3054.1997.tb01830.x

Römheld V (2000) The chlorosis paradox: Fe inactivation as a secondary event in chlorotic leaves of grapevine. J Plant Nutr 23:1629-1643

Snaydon RW, Bradshaw AD (1962) Differences between natural populations of Trifolium repens $\mathrm{L}$. in response to mineral nutrients - I. Phosphate. J Exp Bot 13:422-434 doi: $10.1093 / \mathrm{jxb} / 13.3 .422$

Ström L (1997) Root exudation of organic acids: importance to nutrient availability and the calcifuge and calcicole behaviour of plants. Oikos 80:459-466 doi:10.2307/ 3546618
Ström L, Olsson T, Tyler G (1994) Differences between calcifuge and acidifuge plants in root exudation of lowmolecular organic acids. Plant Soil 167:239-245 doi:10.1007/BF00007950

Susin S, Abadia A, Gonzales-Reyes JA, Lucena JJ, Abadia J (1996) The $\mathrm{pH}$ requirement for in vivo activity of the iron deficiency-induced "turbo" ferric chelate reductase. Plant Physiol 110:111-123

Tiessen H, Moir JO (1993) Characterization of available P by sequential extraction. In: Carter MR (ed) Soil sampling and methods of analysis. Lewis Publishers, Boca Raton, pp 75-86

Toulon V, Sentenac H, Thibaud J-B, Davidian JC, Moulineau C, Grignon C (1992) Role of apoplast acidification by the $\mathrm{H}^{+}$pump. Planta 186:212-218 doi:10.1007/BF00196250

Tyler G (1992) Inability to solubilize phosphate in limestone soils-key factor controlling calcifuge habit of plants. Plant Soil 145:65-70 doi:10.1007/BF00009542

Tyler G (1994) A new approach to understanding the calcifuge habit of plants. Ann Bot (Lond) 73:327-330 doi:10.1006/ anbo.1994.1038

Tyler G, Ström L (1995) Differing organic acid exudation pattern explains calcifuge and acidifuge behaviour of plants. Ann Bot (Lond) 75:75-78 doi:10.1016/S03057364(05)80011-3

Ulrich B (1986) Natural and anthropogenic components of soil acidification. Z Pflanzenernahr Bodenkd 149:702-717 doi:10.1002/jpln.19861490607

Wisskirchen R, Häupler H (1998) Standardliste der Farn-und Blütenpflanzen Deutschlands. Ulmer, Stuttgart

Yesmin L, Gammack SM, Cresser MS (1996) Effects of atmospheric nitrogen deposition on ericoid mycorrhizal infection of Calluna vulgaris growing in peat. Appl Soil Ecol 4:49-60 doi:10.1016/0929-1393(96)00099-6

Yuan G, Lavkulich LM, Wang C (1993) A method for estimating organic bound iron and aluminum contents in soils. Commun Soil Sci Plant Anal 24:1333-1343

Zohlen A, Tyler G (2000) Immobilization of tissue iron on calcareous soil: differences between calcicole and calcifuge plants. Oikos 89:95-106 doi:10.1034/j.16000706.2000.890110.x

Zohlen A, Tyler G (2004) Soluble inorganic tissue phosphorus and calcicole-calcifuge behaviour of plants. Ann Bot (Lond) 94:427-432 doi:10.1093/aob/mch162 